\title{
Potassium Nitrate Priming Affects the Activity of Nitrate Reductase and Antioxidant Enzymes in Tomato Germination
}

\author{
Tulio S. Lara ${ }^{1}$, Jean Marcel S. Lira ${ }^{1}$, Amanda C. Rodrigues ${ }^{1}$, Miroslava Rakocevic ${ }^{2}$ \& Amauri A. Alvarenga ${ }^{1}$ \\ ${ }^{1}$ Department of Biology - Plant Physiology, University of Lavras, Minas Gerais, Brasil \\ ${ }^{2}$ Department of Agriculture, Agricultural Research Institute of Paraná, Paraná, Brasil \\ Correspondence: Jean Marcel S. Lira, Department of Biology - Plant Physiology, University of Lavras, Lavras, \\ Minas Gerais, Brasil. Tel: 55-35-3829-5195. E-mail: lirajms@posgrad.ufla.br
}

\author{
Received: November 4, 2013 Accepted: December 4, $2013 \quad$ Online Published: January 15, 2014 \\ doi:10.5539/jas.v6n2p72 \\ URL: http://dx.doi.org/10.5539/jas.v6n2p72
}

\begin{abstract}
Priming has been used to improve the performance of germination at the field, and potassium nitrate $\left(\mathrm{KNO}_{3}\right)$ is a promising compound for this purpose. The nitrate $\left(\mathrm{NO}_{3}\right)$ could be absorbed, being used in the metabolism of the embryo, through the enzyme nitrate reductase (NR). Besides, the priming could also activate the response of the antioxidant system, becoming the primed seeds more prepared for possible stresses. Thus, the aim of this study was to evaluate the metabolic effect of nitrate in tomato seed germination by the quantification of NR activity, and also evaluate the activity of some antioxidant enzymes as superoxide dismutase (SOD), catalase (CAT) and ascorbate peroxidase (APX). Tomato seeds were primed using solutions of polyethylene glycol (PEG 6000) $-1,1 \mathrm{MPa}, 50 \mathrm{mM} \mathrm{KNO}_{3}$ and $\mathrm{PEG}+\mathrm{KNO}_{3}$. The variables analyzed were germination (germinability, mean germination time, mean germination rate, coefficient of variation of the germination time, uncertainty and synchrony) nitrogen, total proteins and enzymes. The germination data were analyzed using an ANOVA, comparing the averages by Scott-Knott test $(\mathrm{P}<0.05)$. To analyze the nitrogen, protein and enzymatic activities, we used a Kruskal-Wallis test $(\mathrm{P}<0.05)$. The results show an increase in the NR activity, as well as in the antioxidant enzymes. The germination time $(t)$ and germination rate $(v)$ primed in $\mathrm{KNO}_{3}$ had a better performance compared to the other treatments. In conclusion, the observed benefits in tomato seeds primed with $\mathrm{KNO}_{3}$ were related to the activity of the enzyme nitrate reductase in the production of nitrite/nitric oxide, which acted promoting a faster germination.
\end{abstract}

Keywords: $\mathrm{KNO}_{3}$, PEG, priming, germination, tomato

\section{Introduction}

The most sensitive stages, for many crop species submitted to the stress conditions, are seed germination and early seedling growth (Rahimi, 2013). Therefore, the seed germination performance indicators (germinability, germination time, germination rate and synchronization index) are very important for successful crop production.

Seed priming has been used to accelerate the germination, uniform seedling emergence and improve a germination performance under the temperature or drought stresses (Janmohammadi, Dezfuli, \& Sharifzadeh, 2008; Jahangir, Amjad, Afzal, Iqbal, \& Nawaz, 2009). Priming starts some of the metabolic process to occur in germination without a radicle protrusion. Various seed priming techniques have been developed in different medias: hydropriming (water), osmopriming (low water potential solutions such as polyethylene glycol - PEG), halo-priming (salt solutions) (Hamidi, Pirasteh-Anosheh, \& Izadi, 2013; Chen, R. Arora, \& U. Arora, 2010). Seed priming with nitrate solutions resulted in better seed quality and stand establishment in maize field grown (Hanegave, Hunje, Nadaf, Biradarpatil, \& Uppar, 2011). Nitrate solutions helped in shorting a time required for spread of germination in tomato (Farooq, Basra, Saleem, Nafees, \& Chisthi, 2005).

The biological mechanism of priming could be the response of antioxidant systems (Chen \& Arora, 2010). The priming with nitrate solutions stimulates the germination, so Hendricks and Taylorson (1974) suggested that its mechanism could be trough a nitric oxide (NO) synthesis. NO breaks a seed dormancy trough the interaction with the phytochrome signaling pathways, the ethylene biosynthesis, and interplays with reactive oxygen species - ROS (Sírová. Sedlárová, Piterková, Luhová, \& Petrivalsky, 2011). In germinating seeds, the nitrate reductase (NR) and NO synthase (NOS) are among the strongest candidates for the enzymatic sources of NO. Nitrate broke the seed 
dormancy in Arabidopsis thaliana seeds by reducing abscisic acid levels (Matakiadis et al., 2009). It is considered NO dependent in mechanism of dormancy breaking in lettuce seeds (Dong, Tong, Xiao, Cheng, \& Song, 2012).

Tomato shows the primary seed dormancy, which can reduce germination capacity or/and germination speed. When tomato seeds are imbibed in PEG solution, the seed dormancy is broken (Hilhorst \& Downie, 1995). Tomato seeds priming with potassium nitrate $\left(\mathrm{KNO}_{3}\right)$, $\mathrm{PEG}$ or $\mathrm{NaCl}$ have been shown to improve the germination, seedling emergence and the initial growth of various plant species (Govinden-Soulange \& Levantard, 2008; Zhang et al., 2012). Salt solution of potassium nitrate $\left(\mathrm{KNO}_{3}\right)$ was more effective than $P E G$ in improving the germination speed in tomato (Frett et al., 1991).

The benefit role of nitrate in tomato seed germination had been proved in various studies, but its metabolic involvement is still not clear. The aim of this study was to evaluate the metabolic effect of nitrate $\left(\mathrm{KNO}_{3}\right)$ in tomato seed germination by the quantification of the nitrate reductase activity, and the activity of some antioxidant enzymes.

\section{Materials and Methods}

\subsection{Plant material and Priming}

The tomato seeds (Lycopersicon esculentum Mill.), cv. Santa Clara, from the ISLA Co. Ltd, were priming in polyethylene glycol solution (PEG 6000) -1,1 MPa, $50 \mathrm{mM} \mathrm{KNO} 3$ and $\mathrm{PEG}+\mathrm{KNO}_{3}$ (half and half). For the technique of priming, the seeds were treated with continuous aeration at $15^{\circ} \mathrm{C}$ on light, for six days. The primed seeds then were washed twice with distilled water and dried to their original moisture content $\left(7.0^{\circ}\right)$ at $25^{\circ} \mathrm{C}$, to perform the germination tests.

\subsection{Determination of Nitrogen and Total Proteins}

Seeds were dried at $60^{\circ} \mathrm{C}$ for 48 hours, weight and subsequently milled. The milled seeds $(0.01 \mathrm{~g})$ were placed into $2 \mathrm{~mL}$ of concentrated sulfuric acid, and put into the digester block with distillated water, in one micro-distiller. Titration was made with $0.1 \mathrm{~N}$ sulfuric acid. The total $\mathrm{N}$ was quantified by standard Kjeldahl method (Association of Official Analytical Chemistry [AOAC], 1984). Proteins were quantified by Bradford assay (1976).

\subsection{Enzymatic Activities}

Nitrate reductase (NR) activity of seeds was assayed in vivo by the modified method of Delú Filho, Oliveira, Alves and Purcino (1997). Soaked seeds were weighted (0.6 g), put in vacuum for two minutes, and followed by a bath for 75 minutes at $30{ }^{\circ} \mathrm{C}$. Aliquots of $2 \mathrm{ml}$ were withdrawn and $\mathrm{NR}$ activity was measured in vivo by formation of $\mathrm{NO}_{2}$, measured by the absorbance at $540 \mathrm{~nm}$, by using a spectrophotometer BECKMAN, model DU 640. The absorbance values of samples were compared with a standard nitrate curve.

The extracts of the activities of superoxide dismutase (SOD), catalase (CAT) and ascorbate peroxidase (APX) were obtained by a method of Biemelt, Keetman and Albrecht (1998). Ground soaked seeds (0.2 g) were mixed with $100 \mathrm{mM}$ of potassium phosphate buffer $(\mathrm{pH}=7.8)$, EDTA $(0.1 \mathrm{mM})$ and ascorbic acid $(1 \mathrm{mM})$. Extracts were centrifuged at $13,000 \mathrm{~g}$ at $4{ }^{\circ} \mathrm{C}$, for $20 \mathrm{~min}$. Supernatant was collected and used for enzyme assay.

SOD activity was measured by method of Giannopolitise and Ries (1977), adapted for a tomato seed analyses. The reaction mixture included: $50 \mathrm{mM}$ of potassium phosphate buffer $(\mathrm{pH}=7.8), 14 \mathrm{mM}$ of methionine, $75 \mu \mathrm{M}$ of nitro blue tetrazolium, $2 \mu \mathrm{M}$ of riboflavin, $100 \mathrm{nM}$ of EDTA and $20 \mu \mathrm{l}$ of enzyme extract. The reaction was initiated by adding the riboflavin and placing under a light bank consisted on two $15 \mathrm{~W}$ fluorescent tubes, $30 \mathrm{~cm}$ long. The reaction was allowed to continue for $40 \mathrm{~min}$, and was terminated by switching off the light and covering the tubes with a black cloth. Subsequently, the absorbance of reaction mixture was measured at $560 \mathrm{~nm}$ at spectrophotometer BIOTEK, EPOCH model. One unit of SOD activity was defined as the amount of the enzyme required to reach $50 \%$ inhibition of the reaction in the "minus enzyme extract" control, which should have the higher absorbance compared to the samples with the enzyme extract.

CAT activity was measured using the protocol of Havir and McHale (1987). The reaction mixture included 200 $\mathrm{mM}$ of potassium phosphate buffer ( $\mathrm{pH} 7.0$ ), $20 \mu \mathrm{l}$ of enzyme extract, and $120 \mu \mathrm{l}$ of $12.5 \mathrm{mM} \mathrm{H}_{2} \mathrm{O}_{2}$ solution. One unit of CAT activity was defined as the degradation of $1 \mu \mathrm{M}$ of $\mathrm{H}_{2} \mathrm{O}_{2}$ during one minute at $240 \mathrm{~nm}$ (using extinction coefficient $\varepsilon=36 \mathrm{mM}^{-1} \mathrm{~cm}^{-1}$ ).

APX activity was measured by the adaptation of the Nakano and Asada (1981) method for tomato seed analyses. The reaction mixture was composed of $50 \mathrm{mM}$ of potassium phosphate buffer ( $\mathrm{pH} 7.0), 0.5 \mathrm{mM}$ of ascorbic acid (ASA), $0.1 \mathrm{mM}$ of EDTA, $20 \mu \mathrm{l}$ of enzyme extract. $\mathrm{H}_{2} \mathrm{O}_{2}(0.1 \mathrm{mM})$ was added to initiate the reaction. One unit of APX was defined as the conversion of ASA $(1 \mu \mathrm{M})$ into the monodehydroascorbate at $290 \mathrm{~nm}$, during one minute $\left(\varepsilon=2.8 \mathrm{mM}^{-1} \mathrm{~cm}^{-1}\right)$. 


\subsection{Germination Tests}

Four replications with 50 seeds were used as basic sample and placed at each petri dish. The petri dishes were moistened with distilled water and placed in germinator at $20-30{ }^{\circ} \mathrm{C}$ and photoperiod of 12 hours. The number of germinated seeds was recorded daily, during the period of seven days. A seed was considered germinated when its radicle emerged. At the end of this period, the germinability $(G \%)$, mean germination time $(t)$, mean germination rate $(v)$, coefficient of variation of the germination time $\left(C v_{t}\right)$, uncertainty $(U)$ and synchrony $(Z)$ were calculated (Ranal, Santana, Ferreira, \& Mendes-Rodrigues, 2009).

\subsection{Statistical Design}

The experiment was arranged as a completely randomized design with four replications and 50 seeds per replicate for each solution. The priming solutions were $\mathrm{PEG}, \mathrm{KNO}_{3}, \mathrm{PEG}+\mathrm{KNO}_{3}$ and control (unprimed seeds). Germination percentage and germination rate were subjected to analysis of variance (ANOVA). The differences between the means were compared using Scott-Knott test $(\mathrm{P}<0.05)$. Data about the nitrogen and protein concentrations and enzymatic activities were subjected to Kruskal-Wallis test $(\mathrm{P}<0.05)$.

\section{Results}

\subsection{Determination of Nitrogen and Total Protein Content}

The nitrogen level did not vary with priming (Figure 1A), but concentration of total proteins increased with $\mathrm{KNO}_{3}$ (Figure 1B and Table 1).

A

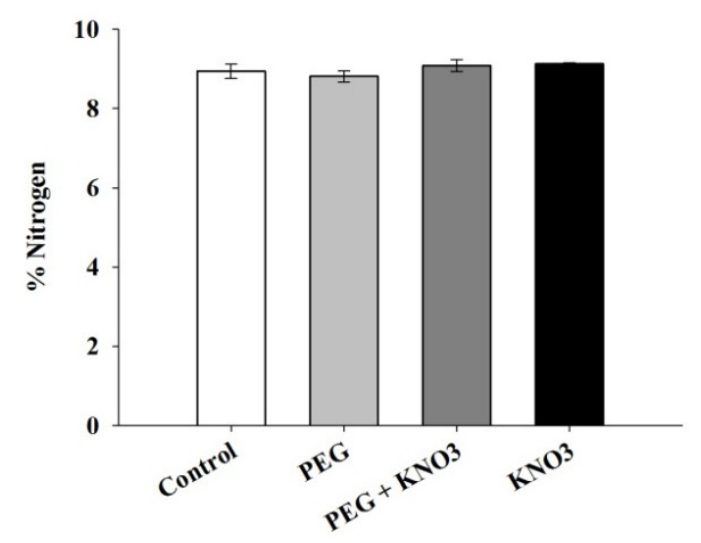

B

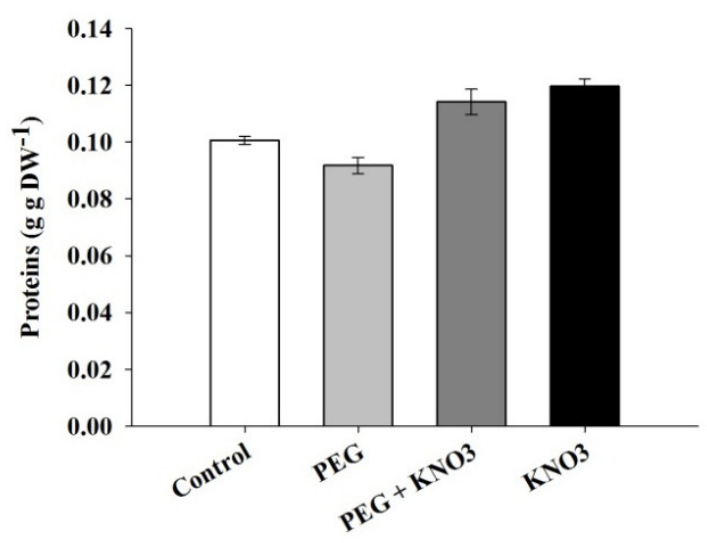

Figure 1. Mean values and standard error for of $\mathbf{A})$ nitrogen percentage and $\mathbf{B}$ ) protein concentration in tomato seeds observed for different priming solutions ( $\mathrm{PEG}, \mathrm{PEG}+\mathrm{KNO}_{3}$ and $\mathrm{KNO}_{3}$ )

Table 1. Mean values and Kruskal-Wallis test for nitrogen percentage and protein concentrations of tomato seeds in different priming solutions (PEG, $\mathrm{PEG}+\mathrm{KNO}_{3}$ and $\mathrm{KNO}_{3}$ )

\begin{tabular}{lllll}
\hline Variable & Treatment & $\mathrm{n}$ & mean & p-value \\
\hline \multirow{4}{*}{ Nitrogen \% } & $\mathrm{KNO}_{3}$ & 3 & 8.81 & \\
& $\mathrm{PEG}$ & 3 & 9.08 & 0.1808 \\
& $\mathrm{PEG}+\mathrm{KNO}_{3}$ & 3 & 9.12 & \\
\cline { 2 - 4 } Proteins & $\mathrm{Control}$ & 3 & 0.10 & \\
& $\mathrm{KNO}_{3}$ & 3 & 0.11 & \multirow{2}{*}{0.02692} \\
& $\mathrm{PEG}$ & 3 & 0.09 & \\
& $\mathrm{PEG}+\mathrm{KNO}_{3}$ & 3 & 0.11 & \\
\hline
\end{tabular}

$\mathrm{p}<0.05$ were considered significant and marked in bold. 


\subsection{Nitrate Reductase Activity}

The supply with $\mathrm{KNO}_{3}$, increased the $\mathrm{NR}$ activity compared to PEG $+\mathrm{KNO}_{3}$, PEG and control (Figure 2, Table 2), promoting an increase in germination speed (Table 4). When primed with PEG and PEG $+\mathrm{KNO}_{3}$ the reduction in NR activity was observed in comparison to the control (Figure 2).

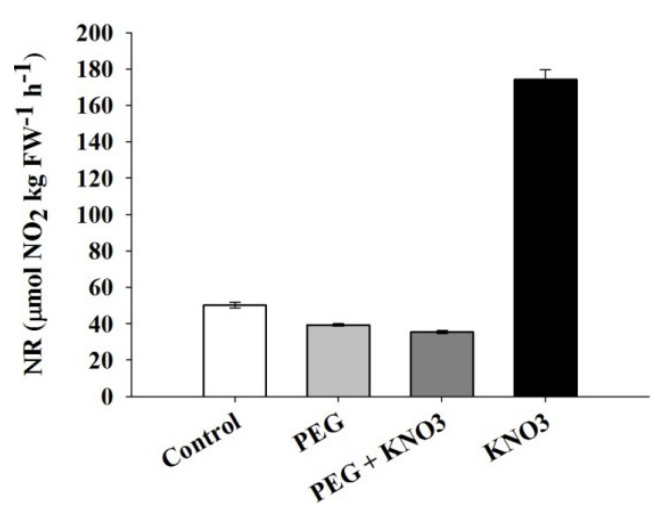

Figure 2. Mean values and standard error for nitrate redutase (NR) activity in tomato seeds priming with different solutions (PEG, $\mathrm{PEG}+\mathrm{KNO}_{3}$ and $\mathrm{KNO}_{3}$ )

Table 2. Mean values and Kruskal-Wallis test of variable nitrate redutase (NR) activity of tomato seeds in different priming solution (PEG, $\mathrm{PEG}+\mathrm{KNO}_{3}$ and $\mathrm{KNO}_{3}$ )

\begin{tabular}{lllll}
\hline Variable & Treatment & $\mathrm{n}$ & mean & p-value \\
\hline \multirow{4}{*}{$\mathrm{NR}$} & $\mathrm{Control}$ & 3 & 50.25 & \\
& $\mathrm{KNO}_{3}$ & 3 & 174.16 & \\
& $\mathrm{PEG}$ & 3 & 39.22 & 0.01556 \\
& $\mathrm{PEG}+\mathrm{KNO}_{3}$ & 3 & 35.46 & \\
\hline
\end{tabular}

$\mathrm{p}<0.05$ were considered significant and marked in bold.

\subsection{SOD, CAT and APX Activity}

In seeds primed with $\mathrm{KNO}_{3}$, an increase in antioxidant system activity was observed (Figure 3). The seeds priming only with $\mathrm{KNO}_{3}$ showed the highest SOD activity compared to the treatments with PEG, PEG + $\mathrm{KNO}_{3}$ and control (Figure 3A, Table 3). Moreover, the CAT activity was highest in $\mathrm{KNO}_{3}$ priming seeds (Figure 3B, Table 3). The reduction in the activity of APX was observed when a priming treatment with $\mathrm{KNO}_{3}$ was compared to those with PEG and $\mathrm{PEG}+\mathrm{KNO}_{3}$, while no difference was observed when compared to control (Figure 3C, Table 3). 

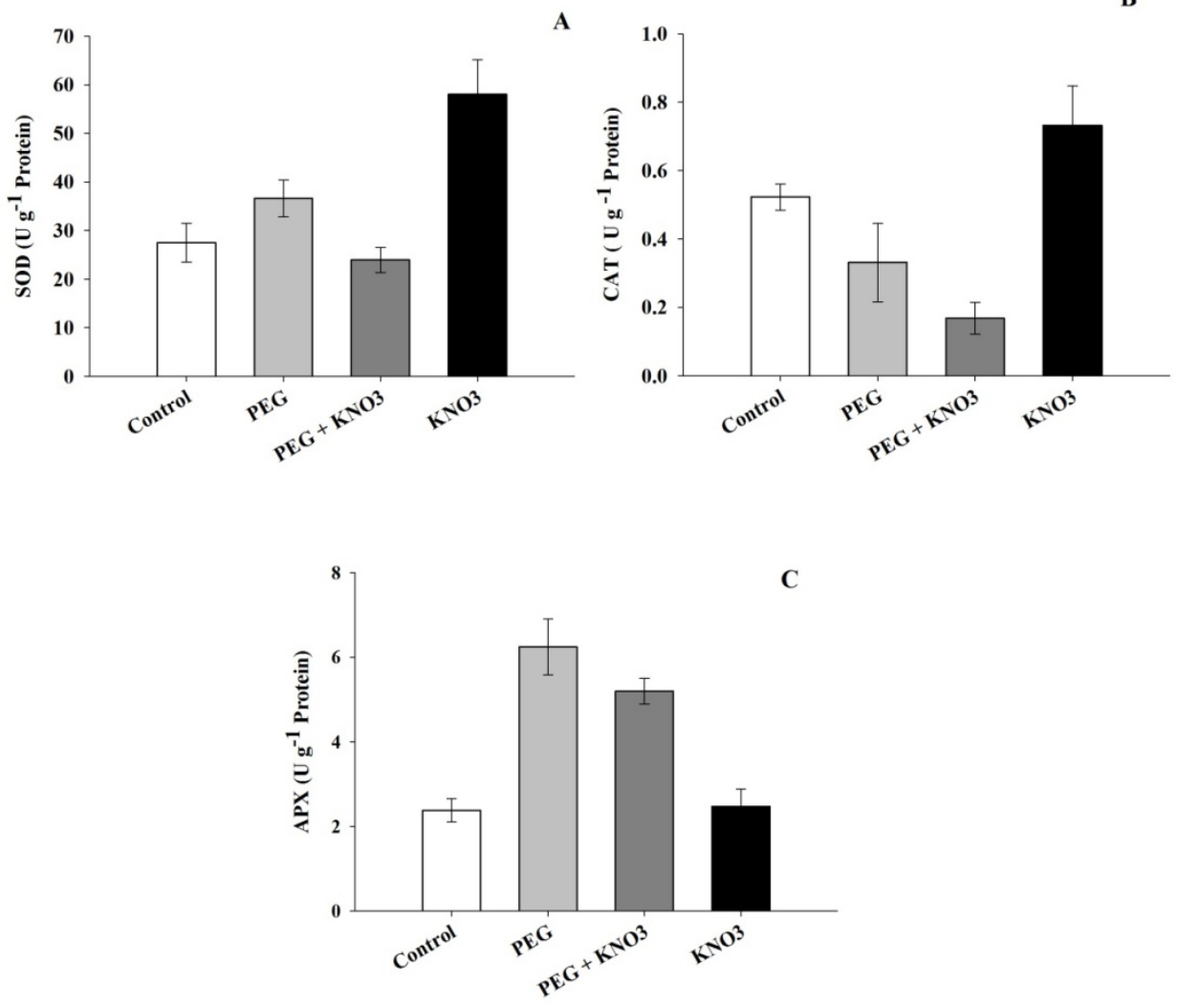

Figure 3. Mean values and standard error for A/ Superoxide dismutase (SOD), B/ catalase (CAT) and C/ ascorbate peroxidase (APX) activities in tomato seeds observed for different priming solutions ( $\mathrm{PEG}, \mathrm{PEG}+\mathrm{KNO}_{3}$ and $\mathrm{KNO}_{3}$ )

Table 3. Mean values and Kruskal-Wallis test for superoxide dismutase (SOD), catalase (CAT) and ascorbate peroxidase (APX) activities of tomato seeds in different priming solution (PEG, PEG $+\mathrm{KNO}_{3}$ and $\mathrm{KNO}_{3}$ )

\begin{tabular}{lllll}
\hline Variable & Treatment & $\mathrm{N}$ & Mean & p-value \\
\hline \multirow{4}{*}{ SOD } & Control & 3 & 27.47 & \\
& $\mathrm{KNO}_{3}$ & 3 & 58.01 & \\
& $\mathrm{PEG}$ & 3 & 36.58 & 0.03069 \\
& ${\mathrm{PEG}+\mathrm{KNO}_{3}}_{3}$ & 3 & 23.94 & \\
\cline { 2 - 4 } $\mathrm{CAT}$ & $\mathrm{Control}$ & 3 & 0.52 & \\
& $\mathrm{KNO}_{3}$ & 3 & 0.73 & \multirow{2}{*}{0.04148} \\
& $\mathrm{PEG}$ & 3 & 0.33 & \\
& ${\mathrm{PEG}+\mathrm{KNO}_{3}}_{3}$ & 3 & 0.17 & \\
\cline { 2 - 4 } APX & $\mathrm{Control}$ & 3 & 2.38 & \\
& $\mathrm{KNO}_{3}$ & 3 & 2.47 & \multirow{2}{*}{0.02998} \\
& $\mathrm{PEG}$ & 3 & 6.24 & \\
& $\mathrm{PEG}+\mathrm{KNO}_{3}$ & 3 & 5.18 & \\
\hline
\end{tabular}

$\mathrm{p}<0.05$ was considered significant and marked in bold. 


\subsection{Germination Tests}

The test of germinability $(G \%)$ did not show any significant differences among the treatments of priming (Table 4). Seeds priming with $\mathrm{KNO}_{3}$ had the shortest germination time $(t)$ and the highest germination rate $(v)$ compared to other treatments. The seeds primed with $\mathrm{KNO}_{3}$ take less time to germinate and sprout more seeds in a shorter time. The uncertainty $(U)$ and synchrony $(Z)$ did not show variation among the treatments, indicating that $\mathrm{KNO}_{3}$ did not interfere in germination synchronization in tomato seeds. Sample homogeneity had not been affected by osmopriming, analyzing the coefficient of variation of the germination time $\left(C v_{t}\right)$.

Table 4. Germination measurements of tomato seeds in different priming solution (PEG, $\mathrm{PEG}+\mathrm{KNO}_{3}$ and $\mathrm{KNO}_{3}$ )

\begin{tabular}{lllllll}
\hline Treatments & $G(\%)$ & $T$ (day) & $C V_{t}(\%)$ & $v\left(\right.$ day $\left.^{-1}\right)$ & $U(\mathrm{bit})$ & $Z$ \\
\hline Control & $87 \mathrm{a}$ & $3.79 \mathrm{a}$ & $24.00 \mathrm{a}$ & $0.26 \mathrm{c}$ & $1.57 \mathrm{a}$ & $0.36 \mathrm{a}$ \\
$\mathrm{PEG}$ & $81 \mathrm{a}$ & $2.93 \mathrm{~b}$ & $30.35 \mathrm{a}$ & $0.34 \mathrm{~b}$ & $1.57 \mathrm{a}$ & $0.38 \mathrm{a}$ \\
$\mathrm{PEG}+\mathrm{KNO}_{3}$ & $84 \mathrm{a}$ & $2.76 \mathrm{~b}$ & $33.38 \mathrm{a}$ & $0.36 \mathrm{~b}$ & $1.61 \mathrm{a}$ & $0.38 \mathrm{a}$ \\
$\mathrm{KNO}_{3}$ & $86 \mathrm{a}$ & $2.37 \mathrm{c}$ & $38.34 \mathrm{a}$ & $0.42 \mathrm{a}$ & $1.67 \mathrm{a}$ & $0.35 \mathrm{a}$ \\
\hline$F(P)$ & $1.25 \mathbf{( 0 . 3 5 )}$ & $50.73(0.001)$ & $2.21 \mathbf{( 0 . 1 6 )}$ & $42.44 \mathbf{( 0 . 0 0 1 )}$ & $0.09 \mathbf{( 0 . 9 6 )}$ & $0.28(\mathbf{0 . 8 6})$ \\
$W(P)$ & $0.96 \mathbf{( 0 . 8 5 )}$ & $0.94 \mathbf{( 0 . 4 8 )}$ & $0.95 \mathbf{( 0 . 6 4 )}$ & $0.97 \mathbf{( 0 . 9 2 )}$ & $0.89 \mathbf{( 0 . 1 2 )}$ & $0.87(\mathbf{0 . 0 7})$
\end{tabular}

Means followed by the same letters in each column are not significantly different based on the Scott-Knott test at 0.05 probability. (G: germinability; $t$ : mean germination time; $C V_{\mathrm{t}}$ : coefficient of variation of the germination time; $v$ : mean germination rate; $U$ : uncertainty; $Z$ : synchrony; F: Snedecor distribution value; boldfaced values indicate significant difference among matrixes (ANOVA; P < 0.05); P: probability). W: statistics of the Shapiro-Wilk test; boldfaced values indicate normality for the residuals of ANOVA $(\mathrm{P}>0.01)$.

\section{Discussion}

NR role in seed germination was related to nitrogen assimilation (Hendricks \& Taylorson, 1974), but in our study the nitrogen in tomato seeds has not change, while total proteins and NR activity was improved. Nitrate can improve the NR activity by de novo synthesis (Somers, Kuo, Kleinhofs, Warner, \& Oaks, 1983), thus priming with $\mathrm{KNO}_{3}$ can increase the synthesis of NR, consequently increase total proteins in tomato seeds. The highest NR activity attended in tomato seeds priming with $\mathrm{KNO}_{3}$ caused the increased activity of the antioxidant system, and the increment of SOD and CAT activities may have been caused by the formation of NO by NR. NR capacity to form nitric oxide through reduction of nitrate to nitrite creates a pool for NO production in plants (Sírová. Sedlárová, Piterková, Luhová, \& Petrivalsky, 2011). In seeds, NO can be formed of a non-enzymatic (Bethke, Bedger, \& Jones, 2004), or through enzyme synthesis (NOS) (Simontacchi, Jasid, \& Puntarulo, 2007). NO production was observed in sorghum seeds during germination, even in control samples (Simontacchi, Jasid, \& Puntarulo, 2004). In primed tomato seeds, the NO is responsible for the positive effects on seed germination at low temperatures (Amooaghaie \& Nikzad, 2013).

Although NO is involved in germination, this molecule is also a reactive oxygen species (ROS), which is countered by the antioxidant system, as indirectly observed in our study, by increasing the activity of SOD and CAT in tomato seeds priming with $\mathrm{KNO}_{3}$. In calluses of two ecotypes of reed (Phragmites communis Trin.) under heat stress, the increased activities of superoxide dismutase (SOD) and catalase (CAT) were observed when sodium nitroprusside (SNP), as an NO donor was applied (Song, Ding, Zhao, Sun, \& Zhang, 2006). In seeds of alfalfa (Medicago sativa) germinated under salt stress, the increased activities of superoxide dismutase (SOD) were recorded when seeds were treated with SNP (Wang, Li, Cui, Xu, Shen, \& Wang, 2012).

Although priming with $\mathrm{KNO}_{3}$ increased the activity of the SOD and CAT in tomato seeds, the reduction in the activity of APX was observed. The reduction of APX activity could be related to small concentrations of $\mathrm{H}_{2} \mathrm{O}_{2}$ required for its operationality, which is owned to its high affinity for substrate (Mittler \& Zilinskas, 1991). The $\mathrm{H}_{2} \mathrm{O}_{2}$ level in seeds affects the germination due to the increased respiration, and consequently, to the $\mathrm{H}_{2} \mathrm{O}_{2}$ concentration rise (Bailly, 2004), and $\mathrm{KNO}_{3}$ primed seeds may have higher $\mathrm{H}_{2} \mathrm{O}_{2}$ production because of higher germination speed. Tomato seeds reduced germination time and improved germination rate when priming with $\mathrm{KNO}_{3}$. A reduction in the average time of germination in seeds primed with $\mathrm{KNO}_{3}$ was observed in other species, as in Gladiolus alatus (Musthaq et al., 2012), while the increased germination rate after a $\mathrm{KNO}_{3}$ priming was recorded in Brassica napus L. under salinity conditions (Abdollahi \& Jafari, 2012). 
The reduction of germination time and the improved germination rate seem to be related to the dormancy breaking through the formation of NO (Dong, Tong, \& Xiao, 2012; Jackobsen et al., 2013). Thus, seed dormancy in tomato makes the priming with $\mathrm{KNO}_{3}$ an useful technique for its germination (Hilhorst \& Downie, 1995). Despite the positive results in germination time and germination rate, a $\mathrm{KNO}_{3}$ priming did not affected the germinability $(G \%)$, the uniformity $\left(C v_{t}\right)$ and the synchrony of germination $(U$ and $Z)$ in this experiment.

The high vigor of tested tomato seeds may be the cause of the lack of priming effect at the germinability. This idea has been evaluated in an experiment with asparagus seeds of low and high vigor. The beneficial effect of priming on germination and vigor was more expressive in the seeds with low physiological quality (Bittencourt, Dias, Dias, \& Araujo, 2005).

\section{Conclusions}

The observed benefits in tomato seeds primed with $\mathrm{KNO}_{3}$ were related to the activity of enzyme nitrate reductase in the production of nitrite/nitric oxide, which acted removing dormancy and promoting a faster germination.

\section{Acknowledgments}

We acknowledgment the UFLA (University of Lavras, Lavras, MG) for structure. This work was support by CNPq (Conselho Nacional de Desenvolvimento Tecnológico) and by FAPEMIG (Fundação de Amparo à Pesquisa de Minas Gerais).

\section{References}

Alboresi, A., Gestin, C., Leydecker, M. T., Bedu, M., Meyer, C., \& Truong, H. N. (2005). Nitrate, a signal relieving seed dormancy in Arabidopsis. Plant Cell and Environment, 28, 500-512. http://dx.doi.org/10.1111/j.1365-3040.2005.01292.x

Amooaghaie, R., \& Nikzad, K. (2013). The role of nitric oxide in priming-induce low-temperature tolerance in two genotypes of tomato. Seed Science Research, 1-9. http://dx.doi.org/10.1017/S0960258513000068

Association of Official Analytical Chemistry. (1984). Official methods of analysis of the Association of Official Analytical Chemists (14th ed.). Arlington.

Bailly, C. (2004). Active oxygen species and antioxidants in seed biology. Seed Science Research, 14, 93-107. http://dx.doi.org/10.1079/SSR2004159

Bethke, P. C., Badger, M. R., \& Jones, R. L. (2004). Apoplastic synthesis of nitric oxide by plant tissues. The Plant Cell, 16, 332-341. http://dx.doi.org/10.1105/tpc.017822

Biemelt, S., Keetman, U., \& Albrecht, G. (1998). Re-Aeration following hypoxia or anoxia leads to activation of the antioxidative defense system in roots of wheat seedlings. Plant Physiology, 116, 651-658. http://dx.doi.org/10.1104/pp.116.2.651

Bittencourt, M. L. C., Dias, D. C. F. S., Dias, L. A. S. D., \& Araújo, E. F. (2005). Germination and vigour of $\begin{array}{lllll}\text { primed } & \text { asparagus } & \text { Seeds. } & \text { Scientia } & \text { Agricola, }\end{array}$ http://dx.doi.org/10.1590/S0103-90162005000400003

Bradford, M. M. (1976). A rapid and sensitive method for quantitation of microgram quantities of protein utilizing the principle of protein-dye binding. Analytical biochemistry, 72, 248-254. http://dx.doi.org/10.1016/00032697(76)90527-3

Chen, K., Arora, R., \& Arora, U. (2010). Osmopriming of spinach (Spinaciaoleracea L. cv. Bloomsdale) seeds and germination performance under temperature and water stress. Seed Science \& Technology, 38, 45-57.

Chen, K., \& Arora, R. (2011). Dynamics of the antioxidant system during seed osmopriming, post-priming germination, and seedling establishment in spinach (Spinaciaoleracea). Plant Science, 180, 212-220. http://dx.doi.org/10.1016/j.plantsci.2010.08.007

Delú Filho, N., Oliveira, L. E. M., Alves, J. D., \& Purcino, A. A. C. (1997). Atividade da redutase do nitrato em plantas jovens de seringueira (Hevea brasiliensis Muell) otimização das condições de ensaio e ritmo circadiano. Revista Árvore, 21, 329-336.

Dong, T., Tong, J., \& Xiao, L. (2012). Nitrate, abscisic acid and gibberellin interactions on the thermoinhibition of lettuce seed germination. Plant Growth Regulation, 66. http://dx.doi.org/191-202.10.1007/s10725-011-9643-5 
El-Araby, M., \& Hegazi, A. Z. (2004). Response of tomato seeds to hydro- and osmo-priming, and possible relations of some antioxidant enzymes and endogenous polyamine fractions. Egyptian Journal of Biology, 6 , 81-93.

Farooq, M., Basra, S. M. A., Saleem, B. A., Nafees, M., \& Chishti, S. A. (2005). Enhancement of tomato seed germination and seedling vigor by osmopriming. Pakistan Journal of Agricultural Sciences, 42, 36-41.

Frett, J. J., Pill, W. G., \& Morneau, D. C. (1991). A Comparison of Priming Agents for Tomato and Asparagus Seeds. HortScience, 26, 1158-1159.

Giannopolitis, C. N., \& Ries, S. K. (1977). Superoxide dismutases. Plant Physiology, 59, $309-314$. http://dx.doi.org/10.1104/pp.59.2.309

Govinden-Soulange, O., \& Levantard, M. (2008). Comparative studies of seed priming and pelleting on percentage and meantime to germination of seeds of tomato (Lycopersicon esculentum Mill.). African Journal of Agricultural Research, 3, 725-731.

Havir, E. A., \& Mchale, N. A. (1987). Biochemical and developmental characterization of multiple forms of catalase in Tobacco leaves. Plant Physiology, 84, 450-455. http://dx.doi.org/10.1104/pp.84.2.450

Hamidi, R., Pirasteh-Anosheh, H., \& Izadi, M. (2013). Effect of seed halo-priming compared with hydro-priming on wheat germination and growth. International Journal of Agronomy and Plant Production, 4, 1611-1615.

Hanegave, A. S., Hunje, R., Nadaf, H. L., Biradarpatil, N. K., \& Uppar, D. S. (2011). Effect of seed priming on seed quality of maize (Zea mays L.). Karnataka Journal Agricultural Sciences, 24, 237-238.

Hendricks, S. B., \& Taylorson, R. B. (1974). Promotion of seed germination by nitrate, nitrite, hydroxylamine, and ammonium salts. Plant Physiology, 54, 304-309. http://dx.doi.org/10.1104/pp.54.3.304

Hilhorst, H. W. M., \& Downie, B. (1995). Primary dormancy in tomato (Lycopersicon esculentum) cv. Moneymaker): studies with the sitiens mutant. Journal of Experimental Botany, 47, 89-97. http://dx.doi.org/10.1093/jxb/47.1.89

Jacobsen, J. V., Barrero, J. M., Hughes, T., Julkowska, M., Taylor, J. M., Xu, Q., \& Gubler, F. (2013). Roles for blue light, jasmonate and nitric oxide in the regulation of dormancy and germination in wheat grain (Triticum aestivum L.). Planta, 238, 121-138. http://dx.doi.org/10.1007/s00425-013-1878-0

Jahangir, M. M., Amjad, M., Afzal, I., Iqbal, Q., \& Nawaz, A. (2009). Lettuce achene invigoration through osmopriming at supraoptimal temperature. Pakistan Journal of Agricultural Sciences, 46, 1-6.

Janmohammadi, M., Dezfuli, P. M., \& Sharifzadeh, F. (2008). Seed invigoration techniques to improve germination and early growth of inbred line of maize under salinity and drought stress. General and Applied Plant Physiology, 4, 215-226.

Matakiadis, T., Alboresi, A., Jikumaru, Y., Tatematsu, K., Pichon, O., Renou, J-P., ... Truong, H-N. (2009). The arabidopsis abscisic acid catabolic gene cyp707a2 plays a key role in nitrate control of seed dormancy. Plant Physiology, 149, 949-960. http://dx.doi.org/10.1104/pp.108.126938

Mittler, R., \& Zilinskas, A. (1991). Purification and characterization of pea cytosolic ascorbate peroxidase. Plant Physiology, 97, 962-968. http://dx.doi.org/10.1104/pp.97.3.962

Mushtaq, S., Hafiz, A. I., U1 Hasan, S. Z., Arif, M., Shehzad, M. A., Rafique, R., ... Iqbal, M. S. (2012). Evaluation of seed priming on germination of Gladiolus alatus. African Journal of Biotechnology, 11, 11520-11523. http://dx.doi.org/10.5897/AJB12.1158

Nakano, Y., \& Asada, K. (1981). Hydrogen peroxide is scavenged by ascorbate-specific peroxidase in spinach chloroplasts. Plant \& Cell Physiology, 22, 867-880.

Rahimi, A. (2013). Seed priming improves the germination performance of cumin (Cuminum syminum L.) under temperature and water stress. Industrial Crops and Products, 42, 454-460. http://dx.doi.org/10.1016/j.indcrop.2012.06.026

Ranal, M. A., Santana, D. G., Ferreira, W. R., \& Mendes-Rodrigues, C. (2009). Calculating germination measurements and organizing spreadsheets. Revista Brasileira de Botanica, 4, 849-855. http://dx.doi.org/10.1590/S0100-84042009000400022

Simontacchi, M., Jasid, S., \& Puntarulo, S. (2004). Nitric oxide generation during early germination of sorghum seeds. Plant Science, 167, 839-847. http://dx.doi.org/10.1016/j.plantsci.2004.05.028 
Simontacchi, M., Jasid, S., \& Puntarulo, S. (2007). Enzymatic sources of nitric oxide during seed germination. In L. Lamattina \& J. Polacco (Eds.) Nitric Oxide in Plant Growth, Development and Stress Physiology (pp.73-90). Berlin/Heidelberg, Springer.

Sírová, J., Sedlárová, M., Piterková, J., Luhová, L., \& Petrivalsky, M. (2011) The role of nitric oxide in the germination of plant seeds and pollen. Plant Science, 118, 560-572. http://dx.doi.org/10.1016/j.plantsci.2011.03.014

Somers, D. A., Kuo, T. M., Kleinhofs, A., Warner, R. L., \& Oaks, A. (1983). Synthesis and Degradation of Barley Nitrate Reductase. Plant Physiology, 72, 949-952. http://dx.doi.org/10.1104/pp.72.4.949

Song, L., Ding, W., Zhao, M., Sun, B., \& Zhang, L. (2006). Nitric oxide protects against oxidative stress under heat stress in the calluses from two ecotypes of reed. Plant Science, 171, 449-458. http://dx.doi.org/10.1016/j.plantsci.2006.05.002

Zhang, M., Wang, Z., Yuan, L., Yin, C., Cheng, J., Wang, L., Huang, J., \& Zhang, H. (2012). Osmopriming improves tomato seed vigor under aging and salinity stress. African Journal of Biotechnology, 11, 6305-6311.

Wang, Y., Li, L., Cui, W., Xu, S., Shen, S. X. W., \& Wang, R. (2012). Hydrogen sulfide enhances alfalfa (Medicago sativa) tolerance against salinity during seed germination by nitric oxide pathway. Plant and Soil, 35, 107-119. http://dx.doi.org/10.1007/s11104-011-0936-2

\section{Copyrights}

Copyright for this article is retained by the author(s), with first publication rights granted to the journal.

This is an open-access article distributed under the terms and conditions of the Creative Commons Attribution license (http://creativecommons.org/licenses/by/3.0/). 